\title{
Self-respect and the Stepford wives
}

\author{
Article
}

Accepted Version

McKinnon, C. (1997) Self-respect and the Stepford wives. Proceedings of the Aristotelian Society, XCVII. pp. 325-330. ISSN 1467-9264 Available at https://centaur.reading.ac.uk/22884/

It is advisable to refer to the publisher's version if you intend to cite from the work. See Guidance on citing.

Publisher: Wiley-Blackwell

All outputs in CentAUR are protected by Intellectual Property Rights law, including copyright law. Copyright and IPR is retained by the creators or other copyright holders. Terms and conditions for use of this material are defined in the End User Agreement.

\section{www.reading.ac.uk/centaur}

\section{CentAUR}

Central Archive at the University of Reading

Reading's research outputs online 


\title{
Self-respect and the Stepford Wives \\ Catriona McKinnon
}

\author{
Proceedings of the Aristotelian Society \\ Vol. XCVII, 1997, pp. 325-30
}

Self-respect, like dignity and integrity, plays a key role in the way we shape our lives yet it remains an underanalysed concept. Questions like, 'Could I live with myself if I did $x$ ?' or fears like the fear of failure address at some level the effect that $x$ or failure may have on our self-respect. We all have levels to which we think we will not sink, and although these lower limits are not always determined by considerations concerning our self-respect, such considerations will often play a crucial role in defining what we will strive not to be or try to become. Self-respect is something that we are loath to give up even in the harshest of circumstances and quick to pursue even at the cost of great toil. Self-respect has at least two components. The first component is connected with a person's conception of herself as having moral value, regardless of her reasons for viewing herself in this way. Sticks and stones cannot possess this general component of self-respect but Kantians, Utilitarians, Christians and Buddhists can all equally well achieve it. This aspect of self-respect is essentially a state of mind. But self-respect must be connected with more than what one believes; it must also be dependent upon what one does. Thus, the second component of self-respect is connected with a person's success at achieving or striving to achieve goals which she finds valuable. The measure of this success will depend upon the person's particular talents and abilities, such that success for the individual in activity $x$ may not coincide with social conceptions of successful $x$-ing. For example, a tone deaf person might respect herself in virtue of being able to hold a tune, but she would not ipso facto be a great singer.

This outline of self-respect occurs at what could be called the meta-level. It gives a general and abstract description of the structural features of selfrespect but remains silent on the question of how potential self-respecters should conceive of themselves as morally valuable, for example, or what kind 
of activity counts as striving to achieve a valued goal. Each selfrespecter will evince these aspects of self-respect in a way that depends on their central values. In addressing my puzzle about self-respect - for reasons which will become clear - I will take it as a virtue of any proposed answer that it remains at this meta-level without making reference to any very specific values which need not be shared by all self-respecters.

The puzzle I want to focus on can be illustrated by considering the following cases. First, take Eric Cantona, the Manchester United striker. Let us assume that Eric conceives of himself as morally valuable, performs well according to his personal standards for all those activities he values, and has no hidden failures or secret despair. Given this it is clear that, love or loathe him, Eric has self-respect.

Second, consider the Stepford Wives. Ignoring the fact that the Stepford Wives in the film were automata, let us stipulate that these are women who perform well at all the activities forming the core of their conception of the good; they are maestros at washing up, masters of cake baking and geniuses at keeping their husbands fed, clothed and sexually satisfied. As one of the Stepford husbands in the film says of his Wife, 'She cooks as good as she looks'. Let us also assume that they conceive of themselves as morally valuable.

Given this it should follow that Eric and the Stepford Wives respect themselves to more or less the same degree. They all conceive of themselves as morally valuable and are all extremely successful in pursuing their personal goals; Eric is one of the best Premier League players, and no-one touches the Stepford Wives when it comes to housekeeping. But do we really want to make this unqualified claim? I would be reluctant to, for although the Stepford Wives may have some self-respect my intuitions are that they do not have as much as Eric. The puzzle I will examine is why we are reluctant to treat the Stepford Wives as exemplary self-respecters when, prima facie, they have many of the attributes and achievements which we normally take to be indicative of self-respect. There must be something about the Stepford Wives that Eric lacks which explains this unease. In trying to pinpoint the 
difference between them I hope to shed some general light on the complex concept of self-respect.

At first sight there are three ways to explain the difference between Eric and the Stepford Wives. First, one could focus on what they do. Second, one could concentrate on the extent to which they exercise certain capacities. And third, one could address the nature of their preferences. Although none of these approaches is acceptable, I will briefly address each of them so as to give a sense of how thorny the problem of the Stepford Wives is.

The most obvious way to explain the difference between Eric and the Stepford Wives is simply to claim that footballing is intrinsically and objectively more worthy of respect than housekeeping, and thus Eric respects himself more than the Stepford Wives because what he does gives him more objective reason to respect himself than what they do. This is an undesirable approach to the problem; self-respect does not necessarily depend upon the value that others place on your personal achievements, and thus the fact that we ourselves may think that housekeeping is inferior to footballing does not explain why we think that a group of housekeepers respect themselves less than a footballer. I believe it better to devote your life to music than to God, but I would not automatically conclude that all successful pianists respect themselves more than a community of chaste Carmelites.

The second approach is to claim that autonomy is a necessary condition for self-respect and Eric has, while the Stepford Wives lack, a high level of autonomy. So the difference between them is the degree to which they exercise their capacity for autonomy.

The main problem with this approach is that positing autonomy as a necessary condition for self-respect, regardless of whether the person in question values autonomy or not, is excessively chauvinistic in so far as it represents only one conception of self-respect that is dependent upon one specific set of values, that is, the values associated with autonomy. For example, independence, self-control and courage. Those conceptions of autonomy which are not associated with specific values like these lie outside 
the scope of the criticism., One of the pre -analytical hallmarks of self-respect is that all sorts of people with diverse characters, capacities and values can equally well respect themselves. Positing autonomy as necessary for self respect makes it the prerogative of those who value autonomy, but any plausible analysis of self-respect must reflect the diversity it encompasses. If self-respect is understood as dependent upon the exercise of capacities which are not held constant in value across many different perspectives then the analysis will be of one conception of self-respect only, rather than of the meta -characteristics which shed real light on this concept.

The third approach is to claim that a person cannot have self -respect unless the preferences she acts upon in pursuing valued goals are authentic. ${ }^{1}$ Thus, authentic preference formation is a necessary condition for self-respect. One prominent account of authentic preferences defines them as objectively contributing to the development of a person as a flourishing human being according to an Aristotelian conception, but one could equally well adopt other conceptions of human flourishing to elucidate authenticity. One could argue, then, that Eric's preferences for football contribute to his flourishing as an individual whereas the Stepford Wives' preferences for catering for their husbands to the exclusion of all else do not and thus Eric has, and the Stepford Wives lack, self-respect.

The authenticity based approach shares the basic flaw of the other two approaches; it requires that one describe a necessary condition for self-respect in terms of one very specific - in this case Aristotelian - set of values. Any analysis of self -respect which proceeds like this cannot reflect the way in which self-respect transcends value differences.

\footnotetext{
${ }^{1}$ Cf. Jean Hampton, 'Selflessness And The Loss Of Self' in Altruism eds. Paul, Miller and Paul (Cambridge: Cambridge University Press, 1993).

${ }^{2}$ Cf. Thomas E. Hill Jnr., 'Servility and Self-Respect', Autonomy and SelfRespect (Cambridge: Cambridge University Press, 1991), pp. 4-18. Hill's account differs from mine in that he defines servility in terms of a failure to
} 
It might seem here that the attempt to address the puzzle of the Stepford Wives at the meta-level without invoking specific values is futile. In what follows I hope to give a satisfactory answer to the puzzle which shows that this is not the case. This answer will further illustrate how self-respect depends more on how one behaves rather than what one values, and illuminate the general structure of the life of a self-respecting person.

So exactly what is wrong with the Stepford Wives? What is it that they have or do which would explain our reluctance to point them out to children as self-respecting role models?

A clue to explaining this reluctance can be found by examining why the Stepford Wives so assiduously perform their household tasks. Their desire to please their husbands is generated - at least initially - by a fear of the censure or criticisms which they will receive if they fail to keep house well. When the primary motivation for an action is fear of this sort, the fear that one will be in some way punished if one fails to meet standards set for one by others then, I submit, that action cannot serve as a basis for self-respect.

This does not imply that the self-respecting person will not fear failure or attempt to avoid criticism per se. As already noted, one of the things we fear most is the loss of self-respect, the failure to succeed by our own lights. But fearing self -criticism is distinct from fearing the criticisms of others, even though these two worries are often intimately connected. People sometimes internalise the criticisms of others and develop a self-attitude which blinds them to their personal successes. One difference between Eric and the Stepford Wives can be found in the explanations we give of their respective fears of failure. Eric's self-criticisms are dependent upon his failure according to what he counts as success, whereas the Stepford Wives' self -criticisms are dependent on a desire to please their spouses, originally inculcated in them by a fear of incurring the censure of their husbands in virtue of what they count as success for their Wives.

We are now more easily able to pinpoint what is worrying about the Stepford Wives and their self-respect. The reason why they fear their husbands' 
censure is their perception of them as their moral superiors, as worth more than they are, and they desire to promote their husbands' interests in virtue of this belief. A person who acts in this way is subservient, and it is the probable subservience of the Stepford Wives that distinguishes their case from that of Eric and explains our unease over their claims to self-respect. In general we could claim that when a person promotes the interests of another primarily because they believe themselves to be morally inferior to that other then they are subservient, and subservience is incompatible with self -respect, however one gains it. ${ }^{2}$ It is compatible with the Stepford Wives' subservience that they are also motivated to promote their husbands' interests out of love or affection. Nonetheless, they remain subservient if their primary motivation is their perception of themselves as morally inferior to their husbands.,

The claim that subservient activity cannot ground self-respect is harmonious with three general, meta-features of self-respect implied by the outline given earlier. First, a person's self -respect is intimately connected with how they behave over and above what they believe, and subservience also manifests itself in behaviour. Subservient behaviour, then, cannot ground self -respect. Second, self-respect is not an all-or-nothing affair, but rather a matter of degree. One can conceive of oneself as more or less morally valuable and be more or less successful at striving to achieve personal goals. Subservience is similarly a matter of degree; more or less of one's actions can be more or less subservient. Third, self-respect is rarely totally absent; a person who conceives of themselves as utterly valueless and has never strived to achieve any personal goals is hard to picture. One explanation of why this is difficult is now available, that is, that it is extremely hard to be totally subservient; to succeed in this all of a person's other-directed actions would have to be premised on a conviction of their moral inferiority. These three claims about

\footnotetext{
${ }^{2}$ Cf. Thomas E. Hill Jnr., 'Servility and Self-Respect', Autonomy and SelfRespect (Cambridge: Cambridge University Press, 1991), pp. 4-18. Hill's account differs from mine in that he defines servility in terms of a failure to appreciate the importance of, or perhaps even to acknowledge the existence of, one's rights.
} 
self-respect are all intuitively appealing, and it is a virtue of the account of the relationship between subservience and self-respect sketched above that it reflects them.

This strategy avoids the problems associated with the three approaches outlined earlier by importing only a minimum of values into the explanation. In pinpointing the source of our worries about the Stepford Wives in their probable subservience I have avoided addressing the question of the worthiness of housekeeping per se or the Wives' failure to live up to various ideals of the good life. To avoid subservience one must view the other who benefits from one's actions as no more valuable than oneself, and this belief is compatible with any number of perspectives. Eric avoids the self-disrespect of the Stepford Wives partly by avoiding subservient behaviour, but if his footballing successes were primarily motivated by a desire to please his dominant wife then this would not be the case. Alternatively, if the Stepford Wives excel at housekeeping but are indifferent to their husbands' commands then - at least in keeping house - they avoid subservience. Subservience has been defined in such a way that many different kinds of lives based around diverse sets of values can evince a subservient structure. This account of the structure of subservience mirrors the account of the structure of self-respect in so far as subservience is not exclusively linked to any one type of life or person. In this way my answer to the puzzle of the Stepford Wives ensures that self-respect retains its character as an attitude not dependent upon the specifics of what a person holds valuable, but rather dependent upon the way in which a person structures their life so as conform to these values.

I would like to thank Veronique Munoz-Darde, Neil Storer and Jo Wolff for many helpful discussions on earlier versions of this paper.

Department of Philosophy, University College London, London WC1E 6BT. 